\title{
МУЛЬТИМЕДІЙНИЙ ПОСІБНИК «КРОК ЗА КРОКОМ»- НОВИЙ ІНСТРУМЕНТ ОСВІТИ ДЛЯ СТАЛОГО РОЗВИТКУ
}

\author{
Микола Близнюк \\ кандидат педагогічних наук, доцент, докторант, \\ Національний педагогічний університет імені М.П. Драгоманова, \\ м. Київ, Україна \\ regcentr@online.ua \\ Валерій Михайленко \\ кандидат географічних наук, доцент \\ Київський національний університет імені Тараса Шевченка, \\ м. Київ, Україна \\ regcentr@online.ua
}

\begin{abstract}
Анотація. Проведено аналіз змістової частини освітніх мультидисциплінарних пакетів Регіонального Екологічного Центру для країн Центральної та Східної Європи «Крок за кроком» та «Зеленого пакета», призначених для поширення наскрізної освіти для сталого розвитку в Україні. Показано, що дидактична основа посібників значною мірою співпадає 3 вимогами освітньої реформи «Нова українська школа». Матеріали посібників можуть задовольнити наявну потребу в навчальних матеріалах шкільної та позашкільної освіти для сталого розвитку щодо формування екологічно орієнтованого мислення та соціальної компетентності учнівської молоді. Поширення цих матеріалів через мережу Інтернет сприяє широкому охопленню цільових груп і має переваги на ринку освітніх послуг своєю інтерактивністю та мобільністю, що $є$ важливим елементом цільової підготовки та перепідготовки 20 тисяч учителів, які будуть задіяні у втіленні шкільної реформи.
\end{abstract}

Ключові слова: освіта для сталого розвитку; ринок освітніх послуг; сталий розвиток; громадянське суспільство; мультимедійний посібник.

Постановка проблеми в загальному вигляді. Поширення та розвиток ідей Саміту ООН «Планета Земля» (Ріо - 92 р.), та освіти для сталого розвитку $(\mathrm{OCP}) є$ одними 3 ключових напрямів діяльності країн світу та міжнародних екологічних організацій. У вересні 2017 року Уряд України представив Національну доповідь «Цілі сталого розвитку: Україна» [1], яка визначає наш поступ для досягнення «Цілі 4: Якісна освіта». Цим документом передбачено реформування освітньої галузі, оновлення стандартів освіти та змісту навчання шляхом упровадження навчальних програм із питань наскрізної ОСР. Формування безпечної для довкілля суспільної поведінки неможливо без упровадження нових освітніх інструментів та організаційних заходів у сфері професійної підготовки вчителів, які $є$ рушійною силою впровадження освітньої реформи «Нова українська школа» [2].

Основними пріоритетами освітньої реформи $є$ виховання в студентів цінностей як невід'ємної частини навчального процесу; а також розвинути 10 ключових компетенцій, якими студенти повинні оволодіти в результаті навчального процесу, зокрема соціальними та громадянськими компетенціями, 
екологічною обізнаністю та здоровим способом життя. У планах Міносвіти до 2018 року підвищити кваліфікацію вчителів молодших класів, створити нові підручники, запровадити національну базу електронних підручників і курсів [3].

Аналіз останніх досліджень і публікацій. У багатьох країнах світу освітні матеріали, присвячені ключовим елементам сталого розвитку, приділяють значну увагу формуванню практичних умінь і навичок, професійної етики й особистісному розвитку і росту майбутніх спеціалістів [4; 5 - 8]. У 2006 році Європейський Парламент та Рада сформулювали основні компетенції європейських систем освіти впродовж усього життя для покращення знань, навичок і вмінь, які допоможуть знайти особисту роль та брати участь у розбудові суспільства. Пізніше, у 2012 році, Свропейська Комісія презентувала свою Стратегію переосмислення освіти, яка передбачала фундаментальну зміну освіти та приділяла більше уваги «результатам навчання», які можуть сприяти поліпшенню проблем XXI століття. Проте основні компетенції та результати навчання не застосовувались для забезпечення того, щоб навички ОСР були міцно вбудовані в усі предметні сфери в рамках традиційних навчальних програм. Успішність ОСР має бути узгодженою з поточними тенденціями в освітніх реформах на національному рівні та представленою ключовим керівникам та експертам.

Невизначеність концептуальних положень сталого розвитку в українському суспільстві часто гальмує формування соціальної компетентності нового покоління, призводить до нівелювання соціальної ролі географічних i суспільних наук, яким доводиться конкурувати 3 традиційним біологічним підходом у сфері збереження якості довкілля [9]. Цьому сприяє недосконала термінологія, яка ототожнює термін «екологія» 3 усіма природничими та соціальними науками, які в англомовних країнах називають «Environmental science» - наука про довкілля. Застарілі моделі предметного підходу особливо відчутні фахівцям у сфері ОСР. Водночас автор [8] зауважує, що відповідно до програм обов'язкових навчальних предметів, українські школярі набувають лише тих знань, що стосуються «класичної» екології в курсі біології (елементи аутекології та синекології), і лише програми з географії для профільних класів характеризують глобальні проблеми. Аналізуючи змістовну частину шкільних програм, автор [8] відмічає, що поняття сталого розвитку розкриваються лише в контексті раціонального використання природних ресурсів у курсі «Фізичної географії України» (8 клас), а навчальних досягнень учнів із цього приводу не передбачено.

Формулювання цілей статті (постановка завдання). Мета - надання інформації про появу на ринку освітніх послуг нового мультимедійного посібника «Крок за кроком» для забезпечення принципу відповідності ОСР потребам суспільного розвитку в Україні. Посібник упроваджується в Україні як результат міжнародної співпраці у сфері освіти з Регіональним Екологічним Центром для країн Центральної та Східної Свропи (РЕЦ), Угорщина. Фінансову підтримку проекту надає Міністерство охорони клімату та довкілля Королівства 
Мультимедійний посібник «Крок за кроком» - новий інструмент освіти для сталого розвитку

Норвегії. Експерти, залучені до адаптації матеріалів «Крок за кроком» для українського ринку освітніх послуг, уважають доцільним ознайомити зацікавлену аудиторію 3 особливостями змістової частини, форм подачі матеріалів і можливостями застосування освітніх матеріалів РЕЦ у шкільній, позашкільній та інклюзивній освіті для поглибленого розуміння концепції сталого розвитку.

Теоретичні основи дослідження. Свропейська система ОСР має свою історію та позитивні здобутки. Уже понад 14 років РЕЦ упроваджує свої інноваційні освітні продукти «Зелений пакет» та «Зелений пакет для юніорів» у країнах Західної Європи. Грунтуючись на величезному регіональному успіху мультимедійних освітніх інструментів у шкільних закладах, експертами РЕЦ був розроблений навчальний посібник «Крок за Кроком» для позашкільної освіти. Його метою було підвищення обізнаності громад про сталий спосіб життя та позитивні зміни, які громадяни можуть робити у своїх громадах. Розвиваючись у тісному співробітництві 3 неурядовими організаціями, «Крок за кроком» дебютував у Білорусі в 2012 році [10]. У 2015 році експерти географічного факультету КНУ узяли активну участь в адаптації та впровадженні цього посібника в Україні.

Методика дослідження. «Крок за кроком»- новий освітній продукт РЕЦ, який виходить цими днями на ринок освітніх послуг України. Матеріали посібника, являють собою віртуальний тур різними об'єктами міської інфраструктури та зонами відпочинку, які люди зазвичай відвідують, ідучи в справах або для розваг. Це насамперед примітивна комп'ютерна гра, яку легко сприймають молодші школярі, але там $є$ місце і для навчання старших дітей та навіть їхніх батьків і дідусів із бабусями.

Цей мультимедійний продукт спрямований на українське суспільство загалом, включаючи муніципальні органи, медіа, бізнес, громадські організації та сім’ї. Він також покликаний сприяти формуванню сталого життєвого стилю та активній поведінці громадян серед школярів та їхніх учителів, організацій громадянського суспільства (ОГС), які проводять просвітницькі заходи серед молоді, та беруть участь у наскрізній освіті для сталого розвитку. Через учителів і учнів головні послання посібника «Крок за кроком» адресовані також членам кожної родини і всім членам суспільства. Його структура побудована у вигляді локацій уявного міста, які представлені на рис. 1.

3 екрану головного меню користувачі можуть відвідати дев'ять типових локацій, натискаючи на дім, школу, супермаркет, парк, озеро, зупинку транспорту, робоче місце, міську площу та бібліотеку. Серія освітніх епізодів у вигляді 48 інформаційних листівок, які супроводжують подорож віртуальними місцями, може бути використана для формування навичок суспільної поведінки. 


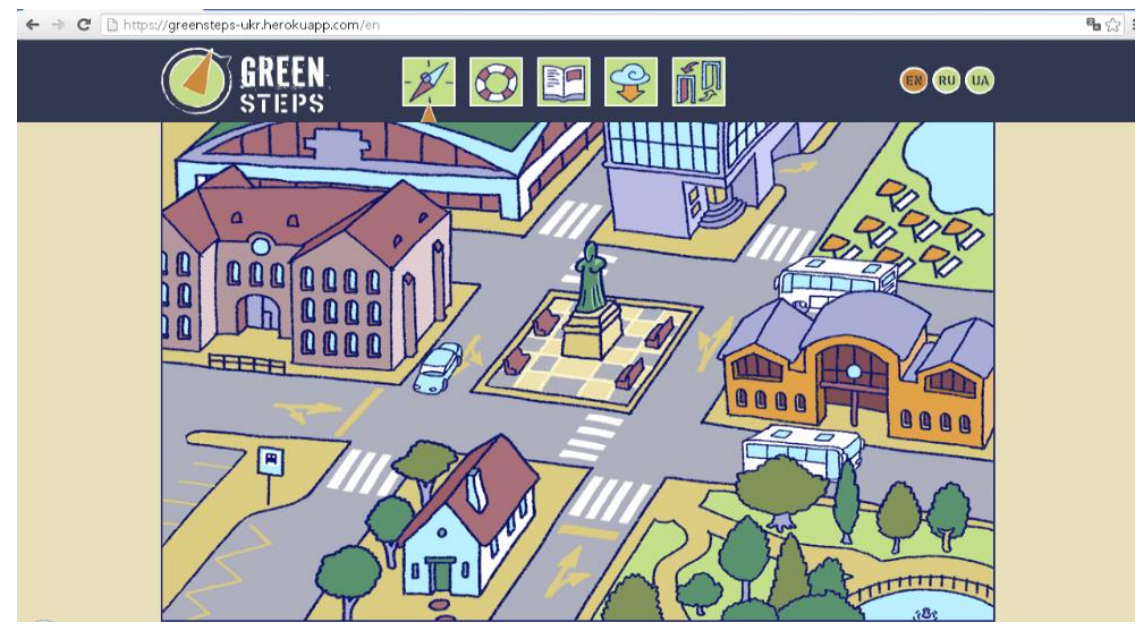

Рис.1. Головне меню посібника «Крок за кроком»

Навігацію по розділах можна здійснити, натискаючи на іконки, розміщені у верхній частині екрану. Міська площа - місце для обговорення 12 модельних історій (дилем). Ці історії є прикладами конфлікту суспільних інтересів та способів знаходження виважених рішень. Погляди різних зацікавлених сторін місцевої влади, бізнес сектору, громадян, екологів, власників автомобілів та студентів - обговорюються учасниками, які мають сформувати власну думку та презентувати іiі.

Потужним інформаційним ресурсом служить бібліотека. Вона містить розмаїття загальної інформації та ресурсів для користувачів посібника. На полицях книжкової шафи стоїть енциклопедія, яка містить інформацію про 293 біотичні види, які є звичними для Центральної Свропи та України. Вони зібрані у вигляді малюнків, фотографій, коротких відео- та аудіосюжетів. Для молодших школярів цікавою буде пізнавальна гра «Що це за звук?», у якій користувач чує звук, а його просять вирішити, яка тварина з показаних на малюнках робить цей звук.

До бібліотеки додана також оновлена версія матеріалів «Зеленого пакета», який успішно пройшов випробування в 18 країнах ЦСЄ. У 2011 році «Зелений пакет» був адаптований для впровадження в Україні. Комплект матеріалів «Зеленого пакета» містить посібник для вчителя з планами уроків, розроблених для 22 тем. Плани уроків побудовані таким чином, щоб ними могли користуватись учителі природничих дисциплін (біології, географії, хімії, фізики). Кожній темі відповідає один або кілька урочних планів. До кожного 3 тематичних розділів додані дидактичні матеріали «Проблеми і Дилеми», які подають опис конкретної проблемної ситуації та дають декілька варіантів іiі вирішення. Учні разом із вчителем розглядають можливі позитивні та негативні наслідки ухвалення того або того рішення.

Особливістю цього посібника $\epsilon$ те, що здобуття нових знань і практичних навичок у користувачів формуються паралельно із вивченням предметних дисциплін. Матеріали посібника не просто надають фактичну інформацію 3 
питань охорони довкілля. Вони допомагають учителю сформувати в школярів нову систему цінностей і демонструють відповідні моделі суспільної поведінки, активної громадянської позиції. Дидактичні матеріали допомагають знаходити відповіді на проблемні питання, які виникають у школі, удома і в громадських місцях.

Формування навичок особистої поведінки закладені в основу шкільної реформи в Україні. Тому певною мірою обидва освітні продукти виконують функцію практикумів, які допомагають співвідносити теоретичні знання 3 реальною дійсністю. Додатковою перевагою $\epsilon$ можливість розвитку користувачами інформаційно-цифрової компетентності: уміння використовувати сучасні цифрові освітні технології і пристрої. «Крок за кроком» розроблений завдяки інноваційним освітнім технологіям, які дозволили включити відео- та аудіоінформацію, поширювати матеріали у форматі дистанційної освіти в мережі Інтернет.

Суспільна значущість та компетентність. Завданням нової української школи є формування екологічно орієнтованого мислення, щоб одержані знання не були простим накопиченням фактів. Саме тому учні з вчителями мають шукати нові форми поширення знань, навичок і вмінь, брати участь в обговоренні проблем, у рольових іграх, учитися враховувати різні думки в процесі прийняття рішень.

Компетентності для демократичного громадянства передбачають уміння ефективно співпрацювати 3 іншими соціальними групами над реалізацією екологічних проектів, розв'язувати проблеми довкілля, залучаючи місцеву громаду та ширшу спільноту. Навички відстоювати власну позицію щодо збереження і охорони довкілля, готовність брати участь у природоохоронних заходах; громадянська відповідальність за стан довкілля напрацьовуються через дилеми або рольові ігри. На відміну від «Зеленого пакета», де дилеми представлені на паперових носіях, «Крок за кроком» забезпечує прямий доступ до 12 дилем в електронному форматі, що дає змогу користуватись відеоапаратурою. Дилеми дають приклад участі громадськості у вирішенні конфліктних ситуацій. Вони формують моделі суспільної поведінки осіб у складних ситуаціях, які часто $є$ типовими для громад.

Інформація про характер впливів на довкілля різних видів діяльності подається через локацію «Робоче місце». В інтерактивному ліфті, який ходить із поверху на поверх, зображені представники 14 різних професій. Натискаючи на фігури, можна отримати доступ до загальної інформації; впливу цих видів діяльності на довкілля та здоров'я, їхній внесок у соціальний та економічний розвиток держави.

«Крок за кроком» та «Зелений пакет» мають на меті покращення системи наскрізної екологічної освіти як одного 3 компонентів ОСР. Для наскрізної екологічної освіти важливо формувати цінності та розвивати нову модель поведінки учнів не лише в школі, але й поширювати екологічне мислення вдома та в суспільстві. Саме такий підхід закладено в ідеологію матеріалів «Крок за 
кроком». Тому цільову аудиторію експерти бачать як заклади неформальної освіти, учнівські гуртки та родини, у яких діти та онуки ходять до школи. Таким способом досягається масштабність впливу матеріалів ОСР в Україні.

Результати дослідження. Методологія «Крок за Кроком» та оновленої версії «Зеленого пакета» значною мірою відповідає тим десяти критеріям формування компетентності, які лежать в основі освітньої реформи, започаткованої Міносвіти України [11]. Це можна побачити із співставлення індикаторів оцінки вмінь та суспільної поведінки, висунутих чинними документами МОН до вчителів та закладів шкільної освіти з цільовим завданням освітніх матеріалів РЕЦ. Тематичні розділи «Зеленого пакета» формують розуміння глобальності екологічних, соціальних та економічних проблем на міжнародному рівні, зосереджуючи увагу на дієвих механізмах покращення стану довкілля в місцевих громадах.

Дидактичні матеріали формують уміння аудиторії обговорювати проблеми, аналізувати та оцінювати роль природних і соціальних явищ, екологічних технологій у сучасному світі. Вони привчають користуватись сучасними термінами і поняттями, аналізувати соціальні проблеми. Лексичний запас спонукає до розвитку української термінології та лексики у сфері охорони довкілля, використовувати іншомовні навчальні джерела інформації. Словниковий запас дає можливість засвоєння запозичених термінів із географічних, біологічних та інших природничих наук. Одночасно автентичність українських, англійських та російських текстів дають можливість користуватись трьома мовами, розширюючи компетентність спілкування іноземними мовами.

Освітні матеріали адаптовані до українського контексту для усвідомлення досягнень українських учених та їхнього внеску у світову науку. Зокрема, належна увага приділена вченню про ноосферу академіка В. Вернадського. Компетентності для демократичного громадянства набуваються через набуті вміння ефективно співпрацювати в команді, упроваджувати геоекологічні проекти, розв'язувати проблеми довкілля, залучаючи місцеву громаду та ширшу спільноту. Інтерактивні групові заняття мають формувати ставлення і моделі власної поведінки в справі збереження й охорони довкілля: відвагу відстоювати власну позицію, готовність брати участь у природоохоронних заходах; персональну відповідальність за стан довкілля та повагу до розмаїття думок $\mathrm{i}$ поглядів.

Компетентність у природничих науках і технологіях набуваються через уміння пояснювати природні явища і технологічні процеси, самостійно чи в групі досліджувати природу, аналізувати і визначати проблеми довкілля; оцінювати значення природничих наук і технологій для досягнення цілей сталого розвитку. Робота вчителів при цьому має бути спрямована на формування відповідного ставлення учня або студента до покращення екологічного стану в місцевій громаді та в Україні; готовності до участі в заходах, направлених на послаблення тиску глобальних екологічних проблем, відповідальності за ощадне використання природних ресурсів. 
Географія впровадження продукту. Сім проектних пропозицій, поданих представниками різних ОГС України та експертами, передбачають організацію і проведення 35 навчальних семінарів та однієї просвітньої кампанії в різних містах України. Вибрані місця: Білозір'я, Бердичів, Черкаси, Христинівка, Фастів, Івано-Франківськ, Канів, Київ, Косів, Кривий Ріг, Лубни, Полтава, Запоріжжя та Золотоноша. Особлива увага буде приділена організації навчальних семінарів у Станично-Луганському та Попаснянському районах Луганської області; та Слов'янському і Волноваському районах Донецької області. Загальна кількість учасників складе близько 1200 осіб, серед них: викладачі, вихователі, представники громадських організацій, місцевої влади та журналісти.

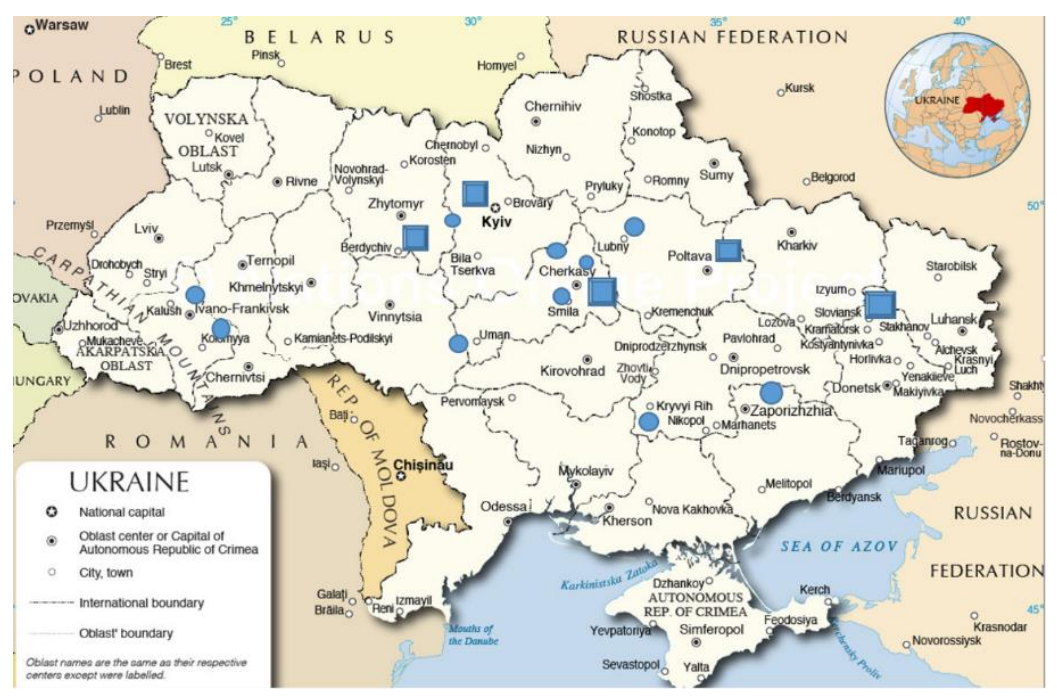

Рис. 2. Географія поширення матеріалів РЕЦ (К. Минджов, 2017)

Географічний факультет Київського національного університету імені Т.Г. Шевченка бере активну участь у поширенні інформації та підготовці вчителів до впровадження «Крок за кроком» у партнерстві 3 Національним екологонатуралістичним центром учнівської молоді (НЕНЦ), який має багаторічний досвід упровадження матеріалів «Зеленого пакета» через свою розгалужену структуру [12]. Близько 100 учасників Конференції НЕНЦ «Модернізація змісту біолого-екологічної освіти: у пошуках оптимальних рішень», Київ, 22 - 23 серпня 2017 р., здійснили віртуальну подорож до екологічного міста й ознайомились із наповненням посібника «Крок за кроком». Заключна конференція, яка узагальнить результати впровадження проекту РЕЦ, має відбутись у Києві на початку 2018 року. Вона буде використана для презентації посібника «Крок за кроком», досвіду поширення цих матеріалів по всій країні, а також відображення кращих практик упровадження в пілотних областях.

Освітня реформа «Нова українська школа» висуває нові вимоги щодо підготовки вчителів. Педагоги мають бути ключовими провідниками реформи в школах. Відповідно вся система підготовки і розвитку педагога та керівника школи потребує змін. Існує нагальна потреба в підготовці вчителів початкових 
класів до роботи в нових українських умовах із 1 вересня 2018 р. У цьому контексті РЕЦ у партнерстві з українськими навчальними закладами може організувати комплексну програму підготовки ОСР, спрямовану на сприяння освітній реформі в Україні. Ця робота планується в межах співпраці 3 географічним факультетом КНУ та НЕНЦ України.

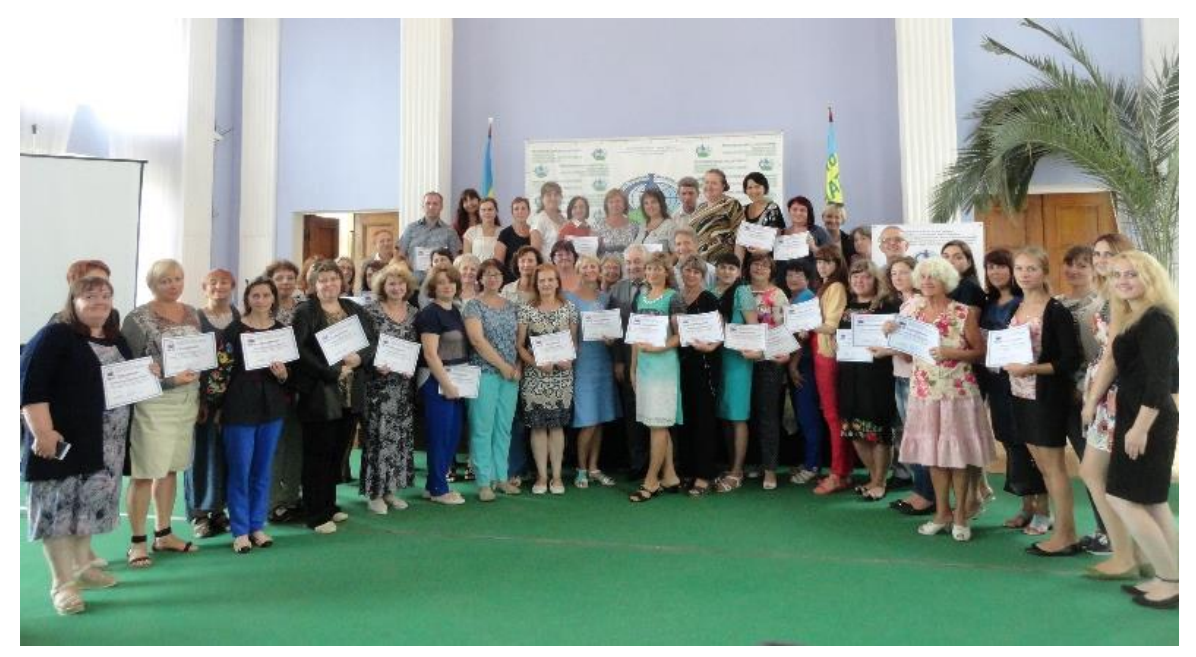

Рис.3. Учасники серпневої конференції вчителів, НЕНЦ, 2017

Міжнародна благодійна організація «Інформаційний центр «Зелене досьє» (www.dossier.org.ua) - партнер програми РЕЦ - провела серію ознайомчих тренінгів щодо роботи з матеріалами та використання їх у просвітницькій діяльності. У тренінгах, що відбулися в Лубнах, Івано-Франківську, Косові та Фастові, брали участь працівники освіти, активісти організацій громадянського суспільства та представники органів влади, загалом понад 100 чоловік, зацікавлених в ефективному поширенні інноваційних методів освіти для сталого розвитку.

Заключна зустріч відбулася в Орхуському інформаційно-просвітницькому центрі (Міністерство екології та природних ресурсів України). До неї долучилися викладачі столичних університетів, фахівці з Державної екологічної академії, Київської дитячої Академії мистецтв, Академії педагогічних наук, експерти міжнародних проектів, представники всеукраїнських та мережевих організацій, які працюють у галузі освіти для сталого розвитку. Учасники зустрічі не лише знайомилися 3 матеріалами нового мультимедійного посібника, а й радилися щодо його подальшого поширення по Україні. Оскільки цей посібник розрахований не лише на використання працівниками формальної освіти, а й передбачає широке залучення до просвітницького процесу всіх небайдужих i поза програмами офіційної школи, для роботи з ним мають застосовуватись різні методи для різних цільових груп. Саме про них сперечалися фахівці, ділилися досвідом уже проведених навчань практики 3 партнерських організацій, які паралельно 3 «Зеленим досьє» наразі поширюють нові матеріали в регіонах України. «Крок за кроком» розроблявся в межах програми «Місцеві ініціативи 
для сталої України» (LINK), яку впроваджує в Україні Регіональний екологічний центр для Центральної та Східної Європи.

Автори посібника тісно співпрацювали 3 українськими експертами та представниками організацій громадянського суспільства задля відображення реальної української ситуації. Матеріали є відкритими для користування. У разі потреби вчителі можуть розробити за його схемою власні урочні плани, доповнюючи та збагачуючи своїми матеріалами. Громадські організації та заклади неформальної освіти можуть користуватись ними під час проведення інформаційно-просвітницьких заходів, спрямованих на вивчення базових понять сталого розвитку та проведення акцій на захист довкілля.

Висновки 3 дослідження і перспективи подальших розвідок у цьому напрямі. Змістова частина освітніх пакетів «Крок за кроком» та «Зеленого пакета» адекватно відображають сучасну систему знань про природу і світ. Синергетична (мультидисциплінарна) форма висвітлення проблемних питань формує комплексне бачення суті проблем, забезпечує вихід за рамки традиційних предметів, у межах яких нема місця для відповіді на гострі запитання сучасності. Дидактична основа посібників вимагає від учителів упровадження нових методів викладання, залучення школярів до інтерактивних способів опанування знань і вмінь. Спільна творча діяльність учителя й учня реалізується в активних формах навчання: діалогу, дискусії, рольових ігор (дилем).

Інтерактивні вправи формують навички суспільної поведінки, необхідної для розвитку творчих здібностей молоді, ощадного ставлення молодого покоління до природи, їхньої персональної відповідальності за долю планети. Посібник не обмежує застосування вчителем власних прийомів, які враховують індивідуальні якості учнів та власний фаховий досвід. Поширення матеріалів через мережу Інтернет здатне значною мірою заповнити прогалини ринку освітніх послуг та бути використаними в умовах реформи шкільної освіти.

Важлива роль у цьому процесі належить професійній підготовці та перепідготовці вчителів (передусім це стосується вчителів географії), яка реалізується на географічному факультеті через навчальні програми, асистентську практику та систему підвищення кваліфікації НЕНЦ. РЕЦ у партнерстві 3 відомими міжнародними й українськими експертами та викладачами міністерств освіти може надати різноманітні навчальні мультимедійні інструменти ОСР для потреб первинних, загальноосвітніх та спеціалізованих українських шкіл з урахуванням досвіду, набутому в 20 країнах Європи та в пілотних областях України.

\section{СПИСОК ВИКОРИСТАНИХ ДЖЕРЕЛ}

1. Національна доповідь «Цілі Сталого Розвитку: Україна» (2017). Взято 3 https://menr.gov.ua/files/docs/Національна\%20доповідь\%20ЦСР\%20України_липень\%202017 \%20ukr.pdf

2. Концепція «Нова українська школа» (2016, 27 жовтня). Взято 3 http://mon.gov.ua/activity/education/zagalna-serednya/ua-sch-2016/ 
Мультимедійний посібник «Крок за кроком» - новий інструмент освіти для сталого розвитку

3. Закон України про освіту. № 2145-19. (2017, 5 вересня). Взято 3 http://zakon2.rada.gov.ua/laws/show/2145-19

4. Wals, A. (2009). Review of Contexts and Structures for ESD. Learning for a Sustainable World. Paris: UNESCO.

5. Hakan, A. (2017). Learning from Dealing with Real World Problems. Education, 137 (4), 413-417.

6. Пустовіт, Н. А. (2006). Освіта для сталого розвитку - важливий напрям підвищення екологічної компетентності вчителя. Вісник Житомирського державного університету. Взято 3 http://eprints.zu.edu.ua/1061/1/06 pnaekv.pdf

7. Пришляк, О. Ю. (2011). Формування інформаційної культури майбутніх педагогів. Науковий вісник Уэсгородського Національного університету, 20, 113-115. Взято 3 https://dspace.uzhnu.edu.ua/jspui/handle/lib/5542

8. Пришляк, О. Ю. (2007). Практична підготовка соціальних педагогів: вітчизняний $\mathrm{i}$ зарубіжний досвід. Педагогічні науки, 44, 348-352. Взято 3 http://ps.stateuniversity.ks.ua/file/issue_44/79.pdf

9. Михайленко, В., Близнюк, М., Денафас, Г., Малькова, Т. і Минджов, К. (2017). Карпатська школа - освітній ресурс для сталого розвитку. Фізична географія та геоморфологія, 1 (85).

10. Johnson, N. (2017, July 24). New lessons for the future. Retrieved from http://www.rec.org/news-item.php?id=1287

11. Гриневич, Л. (2017, 21 серпня). Новий державний стандарт початкової загальної освіти. Всеукраїнська серпнева конференція. Взято 3 http://mon.gov.ua/content/\%D0\%9D\%D0\%BE\%D0\%B2\%D0\%B8\%D0\%BD\%D0\%B8/2017/08/2 1/novij-derzhavnij-standart-pochatkovoyi-zagalnoyi-osviti.pdf

12. Національний еколого-натуралістичний центр учнівської молоді. (б.д.). Взято 3 http://www.nenc.gov.ua/

\section{МУЛЬТИМЕДИЙНОЕ ПОСОБИЕ «ШАГ ЗА ШАГОМ»- НОВЫЙ ИНСТРУМЕНТ ОБРАЗОВАНИЯ ДЛЯ УСТОЙЧИВОГО РАЗВИТИЯ}

\section{Николай Близнюк}

кандидат педагогических наук, доцент, докторант, Национальный педагогический университет имени М.П. Драгоманова, Киев, Украина regcentr@online.ua

\section{Валерий Михайленко}

кандидат географических наук, доцент

Киевский национальный университет имени Тараса Шевченко,

Киев, Украина

regcentr@online.ua

Аннотация. Проведен анализ содержательной части образовательных мультидисциплинарных пакетов Регионального Экологического Центра для стран Центральной и Восточной Европы «Шаг за шагом» и «Зеленого пакета», предназначенных для распространения сквозного образования для устойчивого развития в Украине. Показано, что дидактическая основа пособий в значительной степени совпадает с требованиями образовательной реформы «Новая украинская школа». Материалы пособий могут удовлетворить существующую потребность в учебных материалах школьного и внешкольного образования для устойчивого развития по формированию экологически ориентированного 
мышления и социальной компетентности учащейся молодежи. Распространение этих материалов через сеть Интернет способствует широкому охвату целевых групп и имеет преимущества на рынке образовательных услуг своей интерактивностью и мобильностью, что является важным элементом целевой подготовки и переподготовки 20 тысяч учителей, которые будут задействованы в осуществлении школьной реформы.

Ключевые слова: образование для устойчивого развития; рынок образовательных услуг; устойчивое развитие; гражданское общество; мультимедийное пособие.

\title{
MULTIMEDIA GUIDE “STEP BY STEP” - A NEW EDUCATIONAL TOOL FOR SUSTAINABLE DEVELOPMENT
}

\author{
Nikolay Blyzniuk \\ Candidate of Pedagogical Sciences, Associate Professor, Doctoral Student \\ National Dragomanov Pedagogical University \\ Kiev, Ukraine \\ regcentr@online.ua \\ Valerii Mikhailenko \\ Candidate of Geographical Sciences, Associate Professor \\ Kyiv National Taras Shevchenko University \\ Kiev, Ukraine \\ regcentr@online.ua
}

\begin{abstract}
The content of the educational multidisciplinary packages of the Regional
\end{abstract} Ecological Center for the countries of Central and Eastern Europe "Step by Step" and "Green Package", intended for the spread of cross-cutting education for sustainable development in Ukraine, has been analyzed. It is shown that the didactic basis of the benefits largely coincides with the requirements of the educational reform "New Ukrainian School". The materials of the manuals can satisfy the existing need for educational materials for school and out-of-school education for sustainable development regarding the development of ecologically oriented thinking and social competence of student youth. The dissemination of these materials through the Internet contributes to the broad reach of the target groups and has the benefits of the interaction and mobility of the educational services market, which is an essential element of targeted training and retraining of 20,000 teachers who will be involved in the implementation of school reform.

The analysis of the Regional Ecological Center for the countries of Central and Eastern Europe Educational multidisciplinary packages "Step by Step" and "Green Package" content has been performed in aim to prove their compatibility to the needs of Ukrainian educational market. It is shown that the didactic basis of these tools largely coincides with the requirements of the educational reform "New Ukrainian School". The multimedia toolkit aims to raise public awareness about sustainable lifestyles, citizens' environmental rights, and changes that individuals can make in their lives to contribute to sustainable development. The primary targets are members of civils society organisations. It also contains useful information for educators, students and their families.

The "Step by Step" awareness-raising materials are divided into four sections: a virtual tour around several locations typically visited in everyday activities; 12 model stories; information on 40 topics related to environmental protection and sustainable development; a series of around 50 factsheets that can be used in educational and group activities. The library contains an encyclopaedia with information on 293 species common to Central Europe and the updated version of "Green Package". The materials may satisfy the existing gap of tutorials at Ukrainian Education for Sustainable Development market for school and out of classes activities aimed at training environmentally oriented teachers and developing social competence of youth. The dissemination of 
these materials through the Internet contributes to the broad reach of the targeting groups and has the benefits of the interaction and mobility at the educational services market, which is an essential element of targeted training and retraining of 20,000 teachers, needs to be involved in the implementation of school reform in Ukraine.

Key words: education for sustainable development; market of educational services; sustainable development; civil society; multimedia manual.

\section{REFERENCES}

1. National Report "Sustainable Development Goals: Ukraine" (2017). Retrieved from https://menr.gov.ua/files/docs/Національна\%20доповідь\%20ЦСР\%20України_липень\%202017 \%20ukr.pdf

2. Concept "New Ukrainian School" (2016, October 27). Retrieved from http://mon.gov.ua/activity/education/zagalna-serednya/ua-sch-2016/

3. Law of Ukraine on education. № 2145-19. (2017, September 5). Retrieved from http://zakon2.rada.gov.ua/laws/show/2145-19

4. Wals, A. (2009). Review of Contexts and Structures for ESD. Learning for a Sustainable World. Paris: UNESCO. 413-417.

5. Hakan, A. (2017). Learning from Dealing with Real World Problems. Education, 137 (4),

6. Pustovit, N. A. (2006). Education for sustainable development is an important direction for improving the teacher's environmental competence. Visnyk Zhytomyrskoho derzhavnoho universytetu. Retrieved from http://eprints.zu.edu.ua/1061/1/06 pnaekv.pdf

7. Pryshliak, O. Yu. (2011). Formation of informational culture of future teachers. Naukovyi visnyk Uzhhorodskoho Natsionalnoho universytetu, 20, 113-115. Retrieved from https://dspace.uzhnu.edu.ua/jspui/handle/lib/5542

8. Pryshliak, O. Yu. (2007). Practical training of social educators: domestic and foreign experience. Pedahohichni nauky, 44, 348-352. Retrieved from http://ps.stateuniversity.ks.ua/file/issue_44/79.pdf

9. Mykhailenko, V., Blyzniuk, M., Denafas, H., Malkova, T., \& Myndzhov, K. (2017). Carpathian school is an educational resource for sustainable development. Fizychna heohrafiia ta heomorfolohiia, 1 (85).

10. Johnson, N. (2017, July 24). New lessons for the future. Retrieved from http://www.rec.org/news-item.php?id=1287

11. Hrynevych, L. (2017, August 21). New state standard of elementary general education. Vseukrainska serpneva konferentsiia. $\quad$ Retrieved from http://mon.gov.ua/content/\%D0\%9D\%D0\%BE\%D0\%B2\%D0\%B8\%D0\%BD\%D0\%B8/2017/08/2 1/novij-derzhavnij-standart-pochatkovoyi-zagalnoyi-osviti.pdf

12. National Ecological and Naturalistic Center of Pupils' Youth. (n.d.). Retrieved from http://www.nenc.gov.ua/

Матеріали надійшли до редакції 18.04.2018 р. 